ACTA MYCOLOGICA

Vol. 45 (1): 115-120

2010
Dedicated to Professor Barbara Gumińska on the occasion of her eighty-fifth birthday

\title{
Rinodina degeliana: a corticolous lichen species overlooked in Poland
}

\author{
DARIUSZ KUBIAK \\ Department of Mycology, Warmia and Mazury University in Olsztyn \\ Oczapowskiego 1A, PL-10-957 Olsztyn, darkub@uwm.edu.pl
}

Kubiak D.: Rinodina degeliana: a corticolous lichen species overlooked in Poland. Acta Mycol. 45 (1): 115-120, 2010.

New localities of Rinodina degeliana in Poland are described. The morphology, chemistry, distribution and ecology of the species are discussed and characters that help to differentiate $R$. degaliana from similar lichens are presented. The species is relatively frequent in limehornbeam forests of northern and central Poland.

Key words: lichenized fungi, sorediate species, Rinodina-group, localities, N, C Poland

\section{INTRODUCTION}

The genus Rinodina (Ach.) Gray was represented by 33 species, including 12 epiphytic species, in Poland (Fałtynowicz 2003). Two further taxa, $R$. griseosoralifera Coppins and $R$. degeliana Coppins, were reported by Czarnota and Kukwa (2007) and by Kukwa \& Kubiak (2007), respectively. New localities of Rinodina degeliana

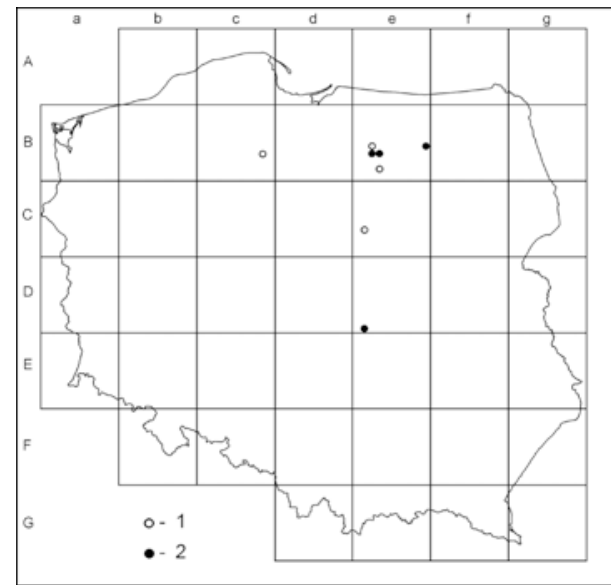

Fig. 1. Rinodina degeliana localities in Poland in the ATPOL grid square: 1 - previously known, 2 - new. 
were recorded during extensive lichenological studies in lime-hornbeam forests in the Masurian Lakeland, N Poland (Fig. 1). Further localities of the species were recorded in two forest reserves in Central Poland. The species seems to be relatively frequent in northern and Central Poland, especially in well preserved lime-hornbeam forests, and may also be frequent in other parts of Poland. R. degeliana may be overlooked or not distinguished because of its fine, inconspicuous sterile thalli.

The aim of this study is to describe $R$. degeliana and to indicate the most important diagnostic characters helpful in its identification during field studies and in the analysis of the herbarium material.

\section{MATERIAL AND METHODS}

The material was collected between 2006 and 2009. Morphological and biochemical characters of the specimens collected were examined using standard lichenological assessment analyses. Thin layer chromatography in solvent $\mathrm{C}$ was used in chemical analyses to differentiate secondary metabolites (Orange et al. 2001). The nomenclature of lichens follows Fałtynowicz (2003), Blanco et al. (2004) and Kauff \& Büdel (2005). The material is deposited in the Herbarium of the Department of Mycology, Warmia and Mazury Univeristy, Olsztyn (OLTC-L), and in the Herbarium of the University of Łódź (LOD-L).

\section{RESULTS AND DISCUSSION}

Rinodina degeliana Coppins - Lichenologist 15 (2): 147 (1983).

Thallus epiphloedic, growing irregularly, composed of compact or scattered areoles. Prothallus not evident. Areoles whitish grey to greenish grey, dull or slightly shiny, irregularly roundish or \pm polygonal, flat but often slightly raised at their margins, $0.2-0.5(-0.7) \mathrm{mm}$ diam. (Fig. 2A). Soralia scattered, less frequently confluent, forming on the underside of raised areole margins, \pm labriform, concolourous with the thallus or lighter - usually pure white (Fig. 2B). Soredia granular, 20-30(-40) $\mu \mathrm{m}$. Apothecia rare or absent. Not recorded in the Polish material.

Chemistry. R. degeliana produces high-concentration atranorin (cf. Coppins 1983), chloratranorin, zeorin and sometimes trace amounts of unidentified terpenoids (Tønsberg 1992). Only atranorin and zeorin were detected in the Polish specimens (cf. Kukwa, Kubiak 2007). Spot test reactions: soralia PD+ intensive yellow, $\mathrm{K}+$ yellow, $\mathrm{C}-$, $\mathrm{KC}-$.

Ecology. $R$. degeliana has been recorded almost exclusively on the bark of deciduous trees of the genera Acer, Betula, Carpinus, Corylus, Quercus, Sorbus, Tilia, mostly on Alnus and Salix in northern Europe (Tønsberg 1992; Mayrhofer, Moberg 2002). It has exceptionally been recorded on the bark of coniferous shrubs (Juniperus). This paper presents the first record of the species on wood. $R$. degeliana has 

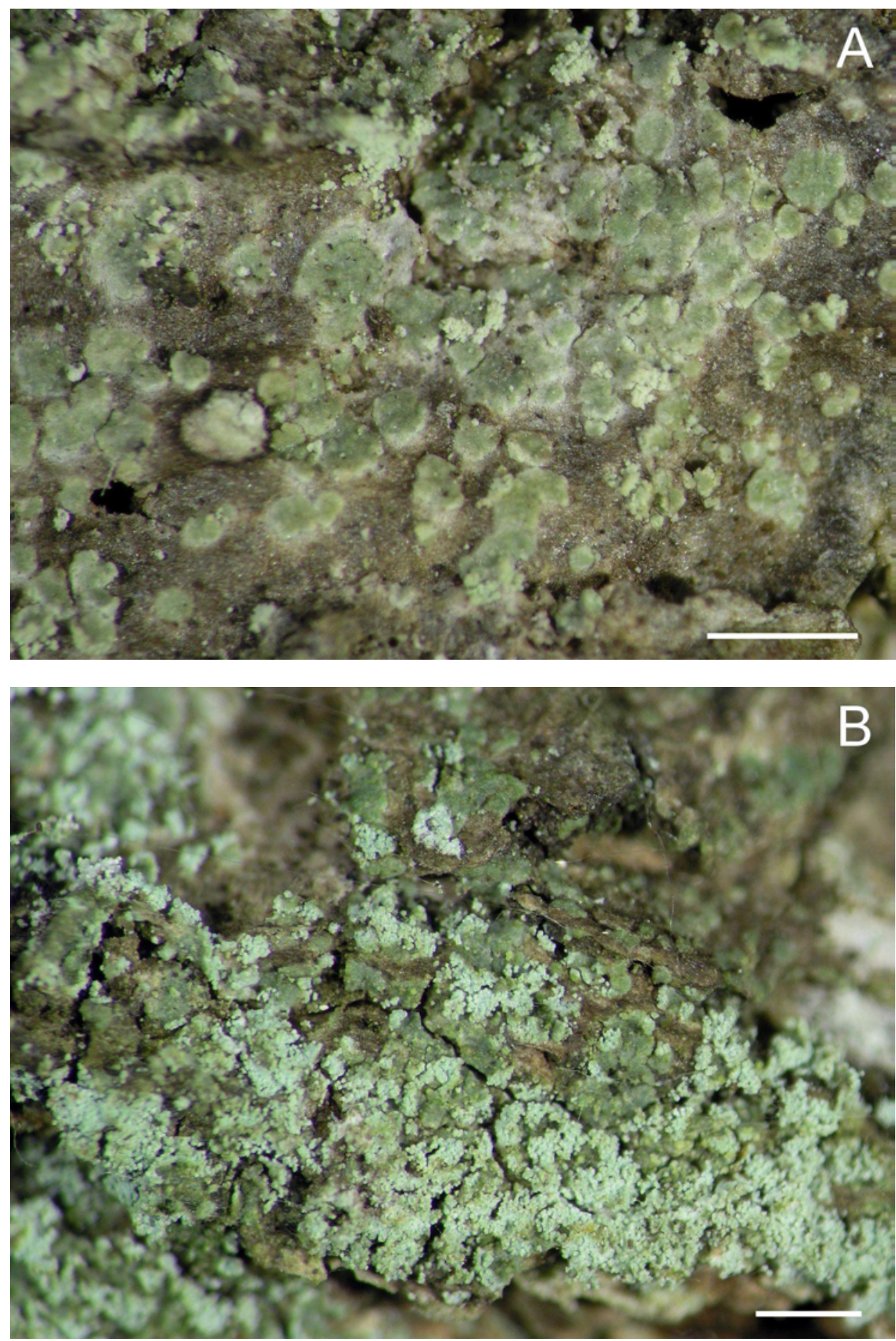

Fig. 2. Rinodina degeliana: A - areolate thallus with few marginal soralia OLTC L-3296; $\mathrm{B}-$ thallus with numerous scattered soralia OLTC L-3297. Scale bars $=1 \mathrm{~mm}$. 
been recorded both in open areas and in mixed or deciduous forests, often in shady and humid sites, e.g. in river valleys.

In Poland, the lichen has been recorded in old deciduous forests (lime-hornbeam forest, heliophilous oak forest) in places usually moderately humid and shaded, exceptionally on the bark of trees growing along roads within or on the edges of forests.

WORLD DISTRIBUTION. Rinodina degeliana is a relatively rare lichen, widespread in the Northern Hemisphere. Outside Europe, the species is known from north-eastern (NE USA, SE Canada) and north-western North America (McCune 2006; Esslinger 2007), and central-eastern Asia (Hauck, Javkhlan 2006; Hauck et al. 2007).

In Europe, the species is known from Sweden (Coppins 1983), Norway (Tønsberg 1992), Great Britain (Coppins et al. 1995), Finland (Vitikainen et al. 1997), Austria (Tønsberg et al. 2001), Estonia (Aptroot et al. 2005), Lithuania (Motiejūnaitè et al. 2005), Poland (Kukwa, Kubiak 2007) and Russia (Stepanchikova et al. 2008). Due to regionally few localities, the lichen has the status of a threatened species in some countries. It is known from only one locality in Great Britain and is classified as a vulnerable species, VU (Woods, Coppins 2003).

Distribution In Poland. Rinodina degeliana is known from 11 localities in northern and central parts of Poland.

SPecimens EXAmined. ATPOL grid square Be 52 - Pojezierze Olsztyńskie Lakeland: Kudypy, Forest Arboretum, lime-hornbeam forest, on Carpinus betulus, together with Fuscidea pusilla, Lecanora expallens, Lepraria elobata, Melanelixia fuliginosa, Pseudosagedia aenea and Rinodina efflorescens, 24 May 2006, leg. D. Kubiak (OLTC-L 3307). Be 59-Pojezierze Mrągowskie Lakeland: ca 1 km W of the Krutyń village, near the road to the Mokre lake, maple-sycamore alley, inside the lime-hornbeam forest, on Acer pseudoplatanus, together with Bacidia cf. subincompta, Lecanora expallens, Lepraria lobificans, Melanelixia fuliginosa, Pertusaria coccodes, Phlyctis argena and Physconia sp., 17 July 2008, leg. D. Kubiak (OLTC-L 3301). Be 62 - Pojezierze Olsztyńskie Lakeland: Las Warmiński nature reserve, forest section No. 657b, 5340’20.6”N, $20^{\circ} 30^{\prime} 06.7$ 'E, lime-hornbeam forest, on Carpinus betulus, together with Biatora efflorescens, Buellia griseovirens, Lepraria elobata, L. incana, Melanelixa fuliginosa and Parmelia sulcata, 21 June 2008, leg. D. Kubiak (OLTC-L 3302); on Carpinus betulus, together with Biatora efflorescens and Buellia griseovirens, 21 June 2008, leg. D. Kubiak (OLTC-L 3303); forest section No. 656a, 5340'25.6”N, 20³0'26.7”N, limehornbeam forest, on Carpinus betulus, together with Biatora efflorescens, Hypogymnia physodes, Lecanora expallens, Lepraria incana, L. rigidula, Parmelia sulcata, Ramalina farinacea and Rinodina efflorescens, 21 June 2008, leg. D. Kubiak (OLTC-L 3304); forest section No. 705a, 533'54.5”N, 20³0'24.7”N, on the bark of Carpinus betulus, together with Cladonia sp., Coenogonium pineti, Micarea prasina s.l., Lecanora expallens, Lepraria incana and Opegrapha sp., 9 July 2008, leg. D. Kubiak (OLTC-L 3305); forest section No. $104,53^{\circ} 40^{\prime} 20.2^{\prime \prime} \mathrm{N}, 20^{\circ} 30^{\prime} 38.5^{\prime} \mathrm{N}$, on the bark of Carpinus betulus, together with Lecanora expallens, Lepraria incana, Micarea prasina s.1., 26 September 2009, leg. D. Kubiak (OLTC-L 3412); forest section

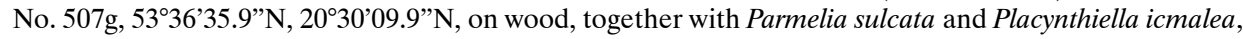
26 September 2009, leg. D. Kubiak (OLTC-L 3413). Be 63 - Las Warmiński nature reserve, forest section No. $177 / 215,53^{\circ} 39^{\prime} 44.6^{\prime \prime} \mathrm{N}, 2^{\circ} 31^{\prime} 16.7^{\prime \prime} \mathrm{E}$, roadside trees, near the forest border, on Acer platanoides, together with Candelariella reflexa, Caloplaca holocarpa, Lecanora hagenii and Phaeophyscia orbicularis, 14 Sept. 2008, leg. D. Kubiak (OLTC-L 3300); forest section No. 252n, 53³9’05.0”N/20³1'59.4”'E, limehornbeam forest, on Carpinus betulus, together with Lepraria incana and Rinodina efflorescens, 10 Oct. 2008, leg. D. Kubiak (OLTC-L 3306). Be 83 - Pojezierze Olsztyńskie Lakeland: Dęby Napiwodzkie nature reserve, oak-hornbeam forests, on Quercus robur, together with Anisomeridium polypori, Lepraria elobata, L. incana, Phlyctis argena and Physconia sp., 30 July 2008, leg. D. Kubiak (OLTC-L 3295); on Quercus robur, together with Cladonia sp., Coenogonium pineti, Hypogymnia physodes, Lepraria lobificans, Micarea prasina s.l., Parmelia sulcata, Phlyctis argena and Rinodina efflorescens (OLTC-L 3296); on Quercus robur, together with Lepraria elobata, L. incana, Phlyctis argena and Rinodina efflorescens, 30 July 2008, leg. D. Kubiak (OLTC-L 3297), on Carpinus betulus, together with Biatora efflorescens, Lepraria elobata and L. incana, 30 July 2008, leg. D. Kubiak (OLTC-L 3294); on Carpinus betulus, together with Phlyctis argena, 30 
July 2008, leg. D. Kubiak (OLTC-L 3299); on Carpinus betulus, together with Biatora efflorescens and Cladonia sp., 30 July 2008, leg. D. Kubiak (OLTC-L 3298). De 91 - Równina Piotrowska Plain, Lasy Spalskie Forest: Konewka nature reserve, heliophilous oak forest, on Quercus sp., together with Hypocenomyce scalaris, Lecanora expallens, Lepraria incana, L. lobificans, Melanelixia fuliginosa, Micarea prasina, 26 June 2009, leg. D. Kubiak (LOD-L 15312); cf. Figure 1.

Note. The following localities: Bc 68 - Bory Tucholskie Forests: ca $2.5 \mathrm{~km}$ W of the Stara Rzeka village, 5339'22”N, 18¹6'40”E, on Tilia cordata, 14 June 2004, leg. M. Kukwa 3317 (UGDA-L 11794); Be

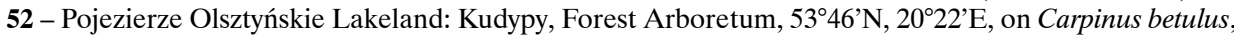
24 May 2006, leg. D. Kubiak (OLTC-L 3312); Be 83 - Pojezierze Olsztyńskie Lakeland: Dęby Napiwodzkie nature reserve, $53^{\circ} 30^{\prime} 15^{\prime \prime} \mathrm{N} / 20^{\circ} 38^{\prime} 43^{\prime \prime} \mathrm{E}$, on Corylus avellana, 17 Sept. 2005, leg. D. Kubiak (OLTC-L 2158), were reported by Kukwa \& Kubiak (2007), while Ce 61 - Równina Raciąska Plain: Dziektarzewo nature reserve, lime-hornbeam forest, on the slope of the Wkra river valley, on Fraxinus excelsior, 26 April 2008, leg. D. Kubiak (OLTC-L 3097) was reported by Kubiak (2009), cf. Figure 1.

Discussion. Rinodina degeliana produces diminutive, inconspicuous thalli that are difficult to distinguish among other crustose sorediate lichens in the field. A considerable part of the specimens reported here was collected by the author accidentally together with other lichens. The species can relatively easily be distinguished in the laboratory. It is characterised by, for instance, crustose to subsquamulose areoles of the thallus, marginal, mostly labriform soralia and atranorin and zeorin content (Tab. 1).

Table 1

Distinguishing features between Rinodina degeliana and superficially similar species (acc. to various sources)

\begin{tabular}{|c|c|c|c|c|}
\hline \multirow[t]{2}{*}{ Features } & \multicolumn{4}{|c|}{ Species } \\
\hline & Rinodina degeliana & $\begin{array}{c}\text { Rinodina } \\
\text { griseosoralifera }\end{array}$ & Rinodina efflorescens & Buellia griseovirens \\
\hline Thallus & $\begin{array}{l}\text { crustaceous to } \\
\text { subsquamulose, } \\
\text { areolate, areoles up } \\
\text { to } 0.7 \text { mm diam., } \\
\text { more or less flat, } \\
\text { adnate to raised at } \\
\text { their edge, whitish } \\
\text { grey to greenish } \\
\text { grey (never tinged } \\
\text { bluish or brownish), } \\
\text { prothallus not } \\
\text { evident }\end{array}$ & $\begin{array}{l}\text { crustaceous, } \\
\text { areolate, areoles } \\
\text { usually up to } \\
0.2 \text { mm diam., } \\
\text { rounded, flat to } \pm \\
\text { convex, scattered } \\
\text { to contiguous, dull } \\
\text { greenish white, } \\
\text { pale grey to greyish } \\
\text { brown, prothallus } \\
\text { indistinct, brown, } \\
\text { visible around } \\
\text { areoles }\end{array}$ & $\begin{array}{l}\text { crustaceous, } \\
\text { composed of } \\
\text { small, } 0.1-0.5 \mathrm{~mm} \\
\text { diam., scattered to } \\
\text { contiguous areoles } \\
\text { with the appearance } \\
\text { of minute } \\
\text { squamules, pale } \\
\text { brownish, prothallus } \\
\text { indistinct, brown, } \\
\text { visible occasionally } \\
\text { between areoles }\end{array}$ & $\begin{array}{l}\text { crustaceous, mostly } \\
\text { distinct, continuous } \\
\text { or irregularly } \\
\text { rimose, sometimes } \\
\text { areolate, grey to } \\
\text { greyish yellow, } \\
\text { prothallus usually } \\
\text { distinct, brownish, } \\
\text { often bluish tinged }\end{array}$ \\
\hline Soralia & $\begin{array}{l}\text { marginal on the } \\
\text { areoles, often more } \\
\text { or less labriform, } \\
\text { developing from } \\
\text { the undersides of } \\
\text { raised margins of } \\
\text { areoles, pure white } \\
\text { to whitish grey; } \\
\text { some areoles often } \\
\text { completely dissolved } \\
\text { into diffuse soralia }\end{array}$ & $\begin{array}{l}\text { discrete, rounded, } \\
\text { flat to convex, } \\
\text { erupting from the } \\
\text { upper surface of the } \\
\text { areoles, occasionally } \\
\text { confluent into larger } \\
\text { sorediate patches, } \\
\text { whitish to blue-grey } \\
\text { (external exposed } \\
\text { soredia) }\end{array}$ & $\begin{array}{l}\text { scattered, bursting } \\
\text { from areoles or } \\
\text { substratum, flat to } \\
\text { convex, occasionally } \\
\text { confluent but } \\
\text { never forming } \\
\text { a continuous } \\
\text { leprose crust, } \\
\text { whitish, greenish } \\
\text { or yellowish, often } \\
\text { tinged brown }\end{array}$ & $\begin{array}{l}\text { mostly discrete, } \\
\text { roundish, convex, } \\
\text { plane or fissure- } \\
\text { shaped, sometimes } \\
\text { few becoming } \\
\text { confluent, greyish, } \\
\text { yellowish or bluish } \\
\text { tinged }\end{array}$ \\
\hline $\begin{array}{l}\text { Chemistry } \\
\text { (major } \\
\text { compounds) }\end{array}$ & $\begin{array}{l}\text { atranorin, } \\
\text { chloratranorin, } \\
\text { zeorin; PD+ } \\
\text { intensive yellow, } \mathrm{K}+ \\
\text { yellow, C- }\end{array}$ & $\begin{array}{l}\text { atranorin, zeorin; } \\
\text { PD- or } \pm \text { faint } \\
\text { yellow, } \mathrm{K}-(\text { exposed } \\
\text { part of pigmented } \\
\text { soredia } \mathrm{K}+\text { brown), } \\
\mathrm{C}-\end{array}$ & $\begin{array}{l}\text { pannarin, } \pm \\
\text { zeorin, efflorescens } \\
\text { unknown pigment; } \\
\text { PD+ orange-red, } \\
\text { K-, C- }\end{array}$ & $\begin{array}{l}\text { atranorin, norstictic } \\
\text { acid and stictic } \\
\text { acid complex; } \\
\text { PD+ yellow, K+ } \\
\text { yellowish red } \\
\text { (forming crystals), } \\
\text { C- or C+ faint } \\
\text { yellow }\end{array}$ \\
\hline
\end{tabular}


The chemistry of only one sorediate lichen, Rinodina griseosoralifera Coppins, is identical to that of $R$. degeliana. However, $R$. griseosoralifera differs by a lower concentration of atranorin, which results in the absence of a strong reaction with K and a usually weak reaction with PD (Coppins 1989; Czarnota, Kukwa 2007). $R$. griseosoralifera is additionally differentiated by flat to \pm convex, oval areoles of the thallus and blue-grey superficial soralia. $R$. degeliana is often accompanied by $R$. efflorescens in the Polish material. The latter sorediate species sometimes produces soralia on the margins of small areoles; however, it never forms soralia on their underside (labriform soralia). $R$. efflorescens is additionally distinguished by its chemistry. It contains pannarin (and additional substances) which causes a colour $\mathrm{PD}$ reaction ( $\mathrm{PD}+$ orange-red) of the soralia, usually green- or brown-pigmented. Because of a similar yellow PD reaction of the soralia, $R$. degeliana may be mistaken with Buellia griseovirens (Turner et Borrer ex Sm.) Almb. B. griseovirens, however, differs by its chemistry (norstictic acid, stictic acid compound), usually a more or less continuous thallus and roundish, surface soralia, often grey- or bluish tinged. Some strongly sorediate specimens of $R$. degeliana may resemble powdery thalli of lichens belonging to the genus Lepraria Ach. $R$. degeliana differs from them by a colour reaction with PD: a distinctly yellow reaction with PD is not obtained for any of the representatives of the genus Lepraria with granular soredia (only L. elobata has a $\mathrm{PD}+$ orange reaction).

Acknowledgements. The author thanks Prof. Krystyna Czyżewska for her permission to publish the locality of Rinodina degeliana from Central Poland. Thanks are also due to the anonymous reviewer for valuable comments and remarks. The study was in part funded by the Polish Ministry of Sciences and Higher Education (grant no. N N304 203737).

\section{REFERENCES}

Aptroot A., Czarnota P., Jüriado I., Kocourková J., Kukwa M., Lõhmus P., Palice Z., Randlane T., Saag L., Sérusiaux E., Sipman H., Sparrius L., Suija A., Thüs T. 2005. New or interesting lichens and lichenicolous fungi found during the 5th IAL Symposium in Estonia. Folia Cryptog. Estonica 41: 13-21.

Blanco O., Crespo A., Divakar P. K., Esslinger T. L., Hawksworth D. L., Lumbsch H. T. 2004. Melanelixia and Melanohalea, two new genera segregated from Melanelia (Parmeliaceae) based on molecular and morphological data. Mycol. Res. 108 (8): 873-884.

Coppins B. J. 1983. A new corticolous sorediate Rinodina from Swedish Lapland. Lichenologist 15:147150.

Coppins B. J. 1989. Rinodina griseosoralifera, a new corticolous sorediate lichen from Western Europe. Lichenologist 21 (2): 169-186.

Coppins B. J., O’Dare A. M., Kantivilas G. 1995. Rinodina degeliana. Bull. Brit. Lichen Soc. 76: 56.

Czarnota P., Kukwa M. 2007. Rinodina griseosoralifera, a lichen species new to the Western Carpathians. Acta Mycol. 42 (2): 287-290.

Esslinger T. L. 2007. A cumulative checklist for the lichen-forming, lichenicolous and allied fungi of the continental United States and Canada. North Dakota State University, Fargo, North Dakota. http://www.ndsu.nodak.edu/instruct/esslinge/chcklst/chcklst7.htm (1 February 2009).

Fałtynowicz W. 2003. The lichens, lichenicolous and allied fungi of Poland - an annotated checklist. W. Szafer Institute of Botany, Polish Academy of Sciences, Kraków.

Hauck M., Dulamsuren C., Mühlenberg M. 2007. Lichen diversity on steppe slopes in the northern Mongolian mountain taiga and its dependence on microclimate. Flora 202: 530-546.

Hauck M., Javkhlan S. 2006. Additions to the lichen flora of Mongolia: records from Khentey and Khangay. Willdenowia 36: 895-912.

Kauff F., Büdel B. 2005. Ascoma ontogeny and apothecial anatomy in the Gyalectaceae (Ostropales, Ascomycota) support the re-establishment of the Coenogoniaceae. Bryologist 108(2): 272-281. 
Kubiak D. 2009. Porosty rezerwatu „Dziektarzewo”. Parki nar. Rez. Przyr. 28(2): 45-55.

Kukwa M., Kubiak D. 2007. Six sorediate crustose lichens new to Poland. Mycotaxon 102: 155-164.

Mayrhofer H., Moberg R 2002. Rinodina. (In:) T. Ahti, P. M. Jørgensen, H. Kristinsson, R. Moberg, U. Søchting, G. Thor (eds). Nordic Lichen Flora. 2. Physciaceae. Nordic Lichen Society, Uddevalla, Sweden, 41-69.

McCune B. 2006. Key to the Lichen Genera of the Pacific Northwest,http://oregonstate.edu/ mccuneb/ pnw.PDF

Motiejūnaitė J., Stončius D., Kukwa M. 2005. Contribution to the Lithuanian flora of lichens and allied fungi. II. Botanica Lithuanica 11 (1): 41-49.

Orange A., James P. W., White F. J. 2001. Microchemical methods for the identification of lichens. British Lichen Society.

Stepanchikova I. S., Himelbrant D. E., Konoreva L. A. 2008. Lichens of Severo-Primorsky Park in St. Petersburg. Vestn. S.-Peterb. un.-ta, Ser. 3: 56-67.

Tønsberg T. 1992. The sorediate and isidiate corticolous, crustose lichens in Norway. Sommerfeltia 14: $1-331$.

Tønsberg T., Türk R., Hofmann P. 2001. Notes on the lichen flora of Tyrol (Austria). Nova Hedwigia 72: 487-497.

Vitikainen O., Ahti T., Kuusinen M., Lommi S., Ulvinen T. 1997. Checklist of lichens and allied fungi of Finland. Norrlinia 6: 1-123.

Woods R. G., Coppins B. J. 2003. A conservation evaluation of British lichens. British Lichen Society, London.

\section{Rinodina degeliana, nadrzewny gatunek porostu przeoczany w Polsce}

\section{Streszczenie}

Rinodina degeliana jest stosunkowo rzadkim porostem, rozpowszechnionym na Północnej Półkuli, poza Europą znany z Ameryki Północnej i Azji. Z Polski gatunek ten znany był dotychczas z trzech stanowisk w północnej (Bory Tucholskie, Pojezierze Olsztyńskie) oraz jednego w środkowej części kraju (Równina Raciąska). W latach 2006-2009 stwierdzono sześć nowych stanowisk tego porostu na obszarze Pojezierza Mazurskiego oraz jedno na Równinie Piotrkowskiej. Uzyskane wyniki wskazują, iż $R$. degeliana jest porostem prawdopodobnie częstym w eutroficznych lasach liściastych północnej i środkowej Polski. Takson ten nie był dotychczas wyróżniany w terenie lub był przeoczany w materiale zielnikowym ze względu na drobne, sterylne plechy. Można przypuszczać, iż dalsze badania w podobnych warunkach ekologicznych, także w innych częściach kraju, pozwolą odszukać kolejne jego stanowiska. W pracy przedstawiono charakterystyczne cechy diagnostyczne pozwalające odróżnić ten gatunek od innych podobnych porostów (Tab. 1). Zaliczyć można do nich: areolkowaty typ plechy, brzeżne, \pm wargowe soralia oraz obecność wtórnych metabolitów - atranoryny i zeoryny. 